\section{OPEN ACCESS}

Edited by:

Bin Wu,

Institute of Chemistry (CAS), China

Reviewed by:

Zhengxu Cai,

Beijing Institute of Technology, China

Zhuping Fei,

Tianjin University, China

*Correspondence:

Yuanyuan $\mathrm{Hu}$

yhu@hnu.edu.cn

Yan Zhao

zhaoy@fudan.edu.cn

Huajie Chen

chenhjoe@163.com

Specialty section

This article was submitted to

Supramolecular Chemistry,

a section of the journal

Frontiers in Chemistry

Received: 25 March 2019

Accepted: 02 May 2019

Published: 29 May 2019

Citation:

Li X, Guo J, Yang L, Chao M, Zheng L,

Ma Z, Hu Y, Zhao Y, Chen H and Liu Y

(2019) Low Bandgap Donor-Acceptor

$\pi$-Conjugated Polymers From

Diarylcyclopentadienone-Fused

Naphthalimides. Front. Chem. 7:362

doi: 10.3389/fchem.2019.00362

\title{
Low Bandgap Donor-Acceptor $\pi$-Conjugated Polymers From Diarylcyclopentadienone-Fused Naphthalimides
}

\begin{abstract}
Xiaolin $\mathrm{Li}^{1}$, Jing Guo ${ }^{2}$, Longfei Yang ${ }^{3}$, Minghao Chao ${ }^{3}$, Liping Zheng ${ }^{1}$, Zhongyun $\mathrm{Ma}^{1}$, Yuanyuan $\mathrm{Hu}^{2 *}$, Yan Zhao ${ }^{3 *}$, Huajie Chen ${ }^{1 *}$ and Yunqi Liu ${ }^{3}$

${ }^{1}$ Key Laboratory for Green Organic Synthesis and Application of Hunan Province, and Key Laboratory of Environmentally Friendly Chemistry and Applications of Ministry of Education, College of Chemistry, Xiangtan University, Xiangtan, China, ${ }^{2}$ Key Laboratory for Micro/Nano Optoelectronic Devices of Ministry of Education \& Hunan Provincial Key Laboratory of Low-Dimensional Structural Physics and Devices, School of Physics and Electronics, Hunan University, Changsha, China, ${ }^{3}$ Department of Materials Science, Institute of Molecular Materials and Devices, Fudan University, Shanghai, China
\end{abstract}

Two novel aromatic imides, diarylcyclopentadienone-fused naphthalimides (BCPONI-2Br and TCPONI-2Br), are designed and synthesized by condensation coupling cyclopentadienone derivatives at the lateral position of naphthalimide skeleton. It has been found that $\mathrm{BCPONI}-2 \mathrm{Br}$ and $\mathrm{TCPONI}-2 \mathrm{Br}$ are highly electron-withdrawing acceptor moieties, which possess broad absorption bands and very low-lying LUMO energy levels, as low as $-4.02 \mathrm{eV}$. On the basis of both building blocks, six low bandgap D-A copolymers (P1-P6) are prepared via Suzuki or Stille coupling reactions. The optical and electrochemical properties of the polymers are fine-tuned by the variations of donors (carbazole, benzodithiophene, and dithienopyrrole) and $\pi$-conjugation linkers (thiophene and benzene). All polymers exhibit several attractive photophysical and electrochemical properties, i.e., broad near-infrared (NIR) absorption, deep-lying LUMO levels (between -3.88 and $-3.76 \mathrm{eV}$ ), and a very small optical bandgap ( $E_{\mathrm{g}}^{\mathrm{opt}}$ ) as low as $0.81 \mathrm{eV}$, which represents the first aromatic diimide-based polymer with an $E_{\mathrm{g}}^{\mathrm{opt}}$ of $<1.0 \mathrm{eV}$. An investigation of charge carrier transport properties shows that P5 exhibits a moderately high hole mobility of $0.02 \mathrm{~cm}^{2} \mathrm{~V}^{-1} \mathrm{~s}^{-1}$ in bottom-gate field-effect transistors (FETs) and a typical ambipolar transport behavior in top-gate FETs. The findings suggest that $\mathrm{BCPONI}-2 \mathrm{Br}$, TCPONI-2Br, and the other similar acceptor units are promising building blocks for novel organic semiconductors with outstanding NIR activity, high electron affinity, and low bandgap, which can be extended to various next-generation optoelectronic devices.

Keywords: diarylcyclopentadienone-fused naphthalimides, D-A conjugated polymers, optical band gap, electrontransporting materials, charge carrier transport

\section{INTRODUCTION}

Soluble donor-acceptor (D-A) conjugated polymers can offer a flexible and tunable electronic structure and optoelectronic properties (Guo et al., 2014; Dou et al., 2015), which encourage the incessant exploration of multiple potential applications in next-generation optoelectronic devices, including organic light-emitting diodes (OLEDs) (Grimsdale et al., 2009), organic photovoltaics 
(OPVs) (Cheng et al., 2009), organic field-effect transistors (OFETs) (Hu et al., 2018; Yang et al., 2018), and organic photodetectors (OPDs) (Gong et al., 2009). By independently selecting or modifying $\mathrm{D} / \mathrm{A}$ segments, one can readily regulate optical properties, electronic structures (bandgap and HOMO/ LUMO energy levels), and charge carrier transport of the target D-A polymers (Hwang et al., 2012; Cui and Wudl, 2013; Zhao et al., 2015; Chen et al., 2016; Fei et al., 2016; Li et al., 2016). Such a D-A strategy has led to the rapid development of numerous D-A conjugated polymers and makes a great contribution to promote device performance in organic electronics (Guo et al., 2014; Dou et al., 2015; Yang et al., 2018). In recent years, some classical organic dyes, such as diketopyrrolopyrrole (DPP) (Zou et al., 2009; Li et al., 2011, 2013c) and isoindigo (IDG) (Stalder et al., 2010; Lei et al., 2011; Mei et al., 2011; Gao et al., 2017), have been successfully used as the acceptor building blocks to construct low bandgap D-A conjugated polymers for various optoelectronic devices, especially in OPVs and OFETs. Hole or electron mobilities higher than $5.0 \mathrm{~cm}^{2} \mathrm{~V}^{-1} \mathrm{~s}^{-1}$ (Chen et al., 2012; Gao et al., 2015) and a power conversion efficiency (PCE) of above $8.0 \%$ (Hendriks et al., 2013) have been reported for the DPP-containing D-A polymers.

In view of the urgent need for electron-transporting materials, aromatic imides like rylene diimides have been widely studied (Zhan et al., 2011). Moreover, they have also become attractive acceptor building blocks for $n$-type conjugated polymers due to the strong electron-deficient feature, high electron mobility, tunable solubility supported by $N$-alkylation, and excellent chemical and photochemical stability (Zhan et al., 2011). So far, the most studied rylene diimides are perylene diimide (PDI, 1) and naphthalene diimide (NDI, 4) (Figure 1). Zhan and co-workers reported the synthesis of the first soluble PDIdithienothiophene copolymers (Zhan et al., 2007), which yielded a moderately high electron mobility of $0.013 \mathrm{~cm}^{2} \mathrm{~V}^{-1} \mathrm{~s}^{-1}$ and a PCE value of $1.5 \%$ when used as the active layers in topgate OFETs and all-polymer OPVs, respectively. Since then, great efforts have been made to structurally modify PDI acceptor units, thereby generating a sets of core-extended PDI analogs (Choi et al., 2011; Usta et al., 2012; Cai et al., 2017, 2018), such as dithienocoronene diimides (DTCDI, 2) (Choi et al., 2011; Zhou et al., 2012) and naphthodiperylenetetraimide (NTDPI, 3) (Guo et al., 2017) (Figure 1). Compared with PDIs, both DTCDI and NTDPI acceptor building blocks possess larger conjugation backbones than PDI, which could facilitate strong intermolecular interactions and charge carriers transport of the polymers (Zhou et al., 2012). Facchetti and co-workers reported the synthesis of soluble D-A polymers containing DTCDI and thiophene units (Usta et al., 2012), which exhibited good hole and electron mobilities of 0.04 and $0.3 \mathrm{~cm}^{2} \mathrm{~V}^{-1} \mathrm{~s}^{-1}$, respectively. Zhao and co-workers synthesized the NTDPI and vinylene-linked $n$-type polymer and afforded an excellent PCE value of $8.59 \%$ in the inverted all-polymer OPVs (Guo et al., 2017).

Naphthalene diimide (NDI, 4, Figure 1) is the other strongly electron-deficient building block for the development of polymer electron-transporting materials. Watson and coworkers. pioneered the use of NDI as an acceptor building block in D-A copolymers with a tunable optical bandgap $\left(E_{\mathrm{g}}^{\mathrm{opt}}\right)$ ranging from 1.7 to $1.1 \mathrm{eV}$ (Guo and Watson, 2008). Later, Facchetti and co-workers reported the synthesis and OFETs properties of an NDI-bithiophene polymer (N2200), which exhibited an impressive electron mobility up to $0.85 \mathrm{~cm}^{2} \mathrm{~V}^{-1} \mathrm{~s}^{-1}$ under ambient conditions (Yan et al., 2009). Thanks to structural optimization and device engineering, copolymers-based NDI units have also very recently provided near state-of-the-art electron mobilities $>7.0 \mathrm{~cm}^{2} \mathrm{~V}^{-1} \mathrm{~s}^{-1}$ (Zhao et al., 2017; Wang et al., 2019). An all-polymer OPV device, reported by Huang and co-workers has been further developed to a benchmark PCE value of 11\% ( $\mathrm{Li}$ et al., 2019), which fabricated from an N2200 acceptor and polymer donor (PTzBI-Si). Recently, a core-extended strategy has been successfully utilized to prepare various heteroaromatic-fused NDI derivatives, such as thiophene-fused NDI (NDTI, 5) (Fukutomi et al., 2013), thiazolefused NDI (NDTZ, 6) (Chen et al., 2013), and pyrazine-fused NDI (BFI, 7) (Figure 1) (Li et al., 2013b). These core-extended NDI units can afford a rigid $\pi$-conjugation backbone with distinct electronic structures as relative-to-simple core-linked NDIs, which has been developed as the promising building blocks for polymer electron-transporting materials (Chen et al., 2013; Fukutomi et al., 2013; Li et al., 2013a). A typical example of the core-extended NDI is tetraazabenzodifluoranthene diimide (BFI, 7) reported by Jenekhe and co-workers; moreover, it was found that a BFI-containing copolymer has a large lateral extension $(2.0 \mathrm{~nm})$ of $\pi$-conjugation and perfect lamellar ordering, thereby achieving high electron mobilities of $0.3 \mathrm{~cm}^{2} \mathrm{~V}^{-1} \mathrm{~s}^{-1}$ (Li et al., 2013a).

Diarylcyclopentadienone-fused naphthalimide (CPONI, Figure 2) is a novel family of aromatic imide building blocks that originally derived from naphthalimide and cyclopentadienone units and is similar in structure to cyclopentadieneones. Wudl and co-workers reported the synthesis and OFET properties of cyclopentadieneones-containing oligomers (Walker et al., 2008; Yang et al., 2008), which demonstrated very small bandgaps as low as $0.9 \mathrm{eV}$ and a moderate hole mobility of $2.26 \times 10^{-2} \mathrm{~cm}^{2} \mathrm{~V}^{-1} \mathrm{~s}^{-1}$ (Yang et al., 2008). Compared with cyclopentadieneone analogs, the combined advantages of both NDI and cyclopentadienone units endow CPONI acceptors with extended $\pi$-conjugation backbone, enhanced electron-withdrawing capacity, as well as tunable solubility that supported by $N$-alkylation. The imide nitrogens in the CPONI units allow attachment of solublizing side chains in the polymer backbone in order to tune solubility and self-organization without disrupting backbone's coplanarity. Thus, CPONI derivatives are of great interest to construct low band-gap D-A conjugated polymers with promising electronic structure and optoelectronic properties. Nevertheless, literature reports on the synthesis, reactivity, and optoelectronic properties of diarylcyclopentadienone-fused naphthalimide derivatives are rarely seen (Ding et al., 2015; Ishikawa et al., 2018). To our knowledge, the CPONI-based polymers have not been reported.

In this article, two novel CPONI-derived acceptor buildingblocks, diphenylcyclopentadienone- fused naphthalimide (BCPONI-2Br) and dithienylcyclopentadienone-fused naphthalimide (TCPONI-2Br) (Figure 2), were designed and synthesized for low bandgap D-A polymers. Herein, 


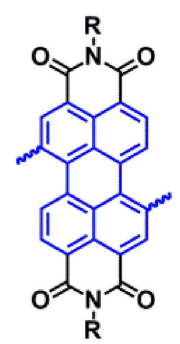

(1)

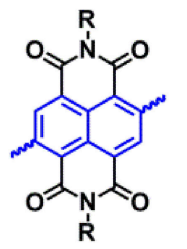

(4)

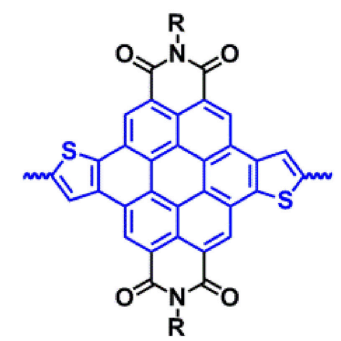

(2)

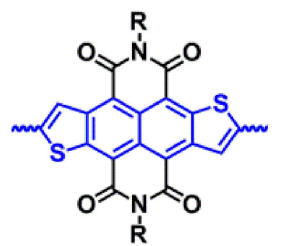

(5)

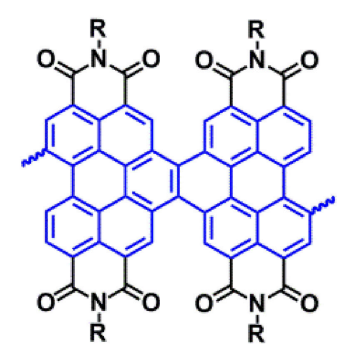

(3)

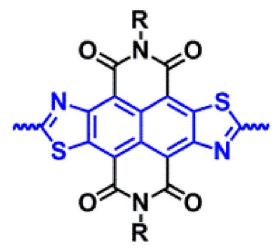

(6)

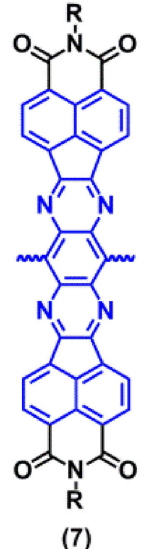

(7)

FIGURE 1 | Some perylene diimide and naphthalene diimide building blocks in conjugated polymers.
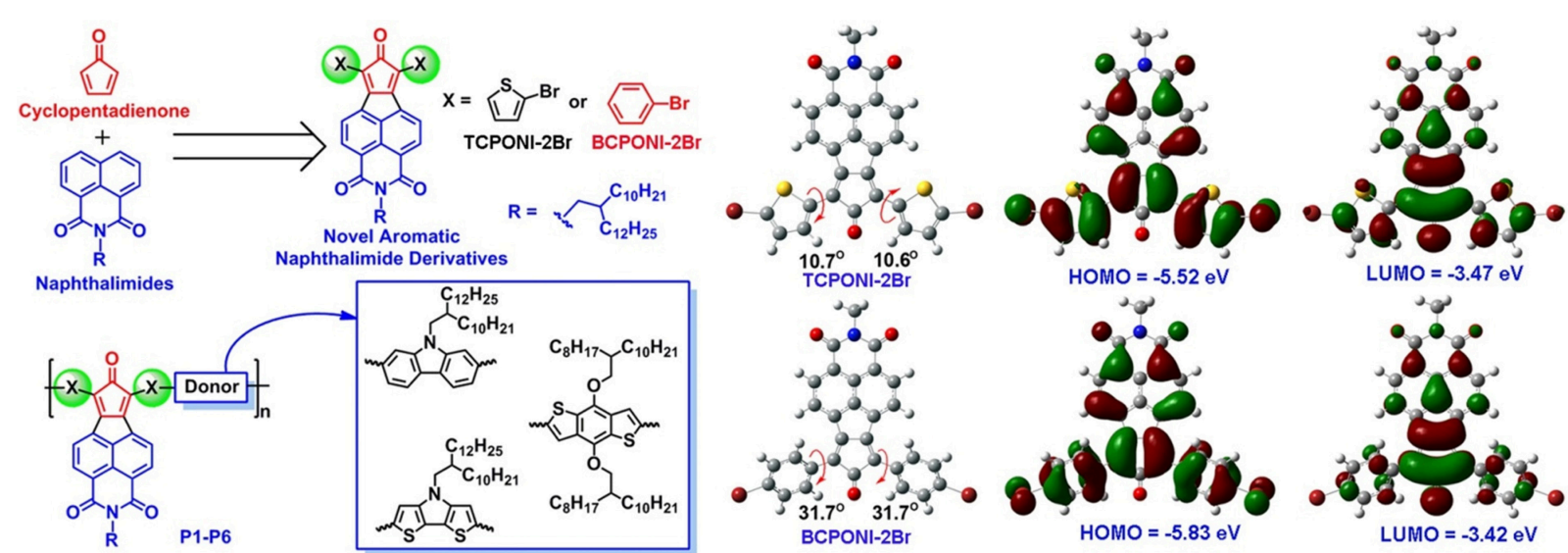

FIGURE 2 | Molecular design and chemical structures of the two monomers (BCPONI-2Br and TCPONI-2Br) and their D-A copolymers (P1-P6). The optimized structures, molecular orbitals, and HOMO/LUMO energy levels of the two monomers as obtained from density functional theory (DFT) calculations.

thiophene and benzene rings were selected as the $\pi$-linker units of TCPONI-2Br and BCPONI-2Br, respectively, in order to manipulate backbone coplanarity, energy levels, and absorption of the target polymers. As revealed by theoretical calculations, the dihedral angles of thiophene-flanked TCPONI-2Br (ca. 10.6 and $10.7^{\circ}$ ) are smaller than those of benzene-flanked BCPONI-2Br (ca. $\left.31.7^{\circ}\right)$, indicating better backbone coplanarity for TCPONI-2Br. Interestingly, the attachment of electron-rich thiophene units endows TCPONI-2Br with a slightly reduced LUMO value (ca. $-3.47 \mathrm{eV}$ ) but sharply improved the HOMO value (ca. $-5.52 \mathrm{eV}$ ) relative to BCPONI-2Br. Such deep-lying LUMO values indicate that TCPONI-2Br (ca. $-3.47 \mathrm{eV}$ ) and BCPONI-2Br (ca. $-3.42 \mathrm{eV}$ ) are promising strong acceptor units for electron-transporting polymers. By using both building blocks as the electron acceptors, six novel D-A conjugated polymers with different electron-donating capability donor units (carbazole, benzodithiophene, and dithienopyrrole) were prepared by Suzuki or Stille coupling reactions. The polymers exhibit very attractive photophysical and electrochemical properties, i.e., broad near-infrared (NIR) absorption extended to $1,600 \mathrm{~nm}$ and adjustable $E_{\mathrm{g}}^{\mathrm{opt}}$ values from 0.81 to $1.55 \mathrm{eV}$, which was realized by employing different donor units and $\pi$-conjugation linkers. To our satisfaction, an ultralow $E_{\mathrm{g}}^{\mathrm{opt}}$ of $0.81 \mathrm{eV}$ was achieved for TCPONI-containing polymer (P6), which represents the first aromatic diimide-based polymer with the $E_{\mathrm{g}}^{\mathrm{opt}}<1.0 \mathrm{eV}$.

\section{EXPERIMENTAL SECTION}

\section{General Measurements}

Nuclear magnetic resonance spectra $\left({ }^{1} \mathrm{H}\right.$ NMR and $\left.{ }^{13} \mathrm{C} N M R\right)$ were collected on a Bruker AVANCE 400 spectrometer. Mass 
spectrometry (MALDI-TOF-MS) was performed on a Bruker AutoflexTM III instrument. Molecular weight was determined by high temperature gel permeation chromatography $\left(150^{\circ} \mathrm{C}\right.$ in 1,2,4-trichlorobenzene) on a Polymer Labs PL 220 system. UVvis-NIR absorption spectroscopy was measured using a PerkinElmer Lamada $750 \mathrm{UV} /$ vis spectrometer. Thermogravimetric analysis (TGA) was recorded on a Perkin-Elmer TGA-7 Analyzer with a heating rate of $10^{\circ} \mathrm{C} \mathrm{min}^{-1}$. Differential scanning calorimetry (DSC) was measured on a DSC Q10 instrument with the heating/cooling rates of $10^{\circ} \mathrm{C} \mathrm{min}^{-1}$. Cyclic voltammetry (CV) was performed on an electrochemistry workstation (CHI660E, Chenhua Shanghai) using a three-electrode cell. For the characterization of small molecules, three-electrode cell with a Pt wire counter electrode, a $\mathrm{Ag} / \mathrm{AgCl}(\mathrm{KCl}$, Sat'd) reference electrode, and a glassy carbon working electrode was utilized. For the measurement of polymers, a $\mathrm{Pt}$ wire, a $\mathrm{Ag} / \mathrm{AgCl}(\mathrm{KCl}$, Sat'd) electrode and a Pt disk drop-coated with polymer film were used as the counter, reference electrode, and working electrode, respectively. The electrolytes were anhydrous and $\mathrm{N}_{2}-$ saturated tetrabutylammonium hexafluorophosphate (TBAPF6, $0.1 \mathrm{M}$ ) solutions in dichloromethane or acetonitrile. A Fouriertransform infrared spectroscopy (FT-IR) was carried out on a Nicolet 6700 FT-IR spectrometer in a scan range from 4,000 to $600 \mathrm{~cm}^{-1}$. The film surface morphology was characterized by atomic force microscopy (AFM, Bruker Multi-Mode 8 microscope) using a tapping mode. Grazing incidence X-ray diffraction (GIXRD) experiments were performed to characterize film organization. The polymer film samples were illuminated at a constant incidence angle of $0.2^{\circ}$.

\section{Materials and Synthesis}

Tetrahydrofuran (THF) and chlorobenzene were dried and distilled prior to use. All the reagents and chemicals were purchased from Chem Greatwall, Derthon, and Alfa Aesar. Some important intermediates, including 1,3-dithiophenyl-2propanone (1) (Walker et al., 2008), 1,3-bis(4-bromophenyl)-2propanone (3) (Walker et al., 2008), 2-(2-decyltetradecyl)-1Hindeno[6,7,1-def]isoquinoline-1,3,6,7(2H)-tetraone (4) (Li et al., 2013b), $\quad N$-(2-decyltetradecyl)-2,7-bis-(4,4,5,5-tetramethyl1,3,2-dioxaborolane-2-yl)carbazole (Kim et al., 2011), 2,6-bis(trimethyltin)-4,8-di(2-hexyl)decyloxybenzo[1,2- $b ; 3,4$ -

$b^{\prime}$ ]dithiophene (Mei et al., 2013), and 2,6-bis(trimethylstannyl)$N$-(2-decyltetradecyl)dithieno $\left[3,2-b: 2^{\prime}, 3^{\prime}-d\right]$ pyrrole (Zhang et al., 2010), were synthesized according to literature procedures, respectively.

\section{Synthesis of Compound 2}

Under nitrogen, a mixture of 1,3-dithiophenyl-2-propanone $(1.2 \mathrm{~g}, 5.40 \mathrm{mmol})$ and $\mathrm{CHCl}_{3}(25 \mathrm{~mL})$ was stirred at $0^{\circ} \mathrm{C}$. Next, $2.11 \mathrm{~g}$ of $\mathrm{N}$-bromobutanimide (NBS) $(11.88 \mathrm{mmol}$ ) was slowly added to the reaction mixture. After stirring for $5 \mathrm{~h}$ at room temperature, the reaction was quenched with water. The organic layer was extracted by $\mathrm{CH}_{2} \mathrm{Cl}_{2}$ and dried over anhydrous $\mathrm{MgSO}_{4}$. After removal of the solvent, the crude product was purified by column chromatography on silica gel using a mixed eluent of petroleum ether and $\mathrm{CH}_{2} \mathrm{Cl}_{2}(3: 1, \mathrm{v} / \mathrm{v})$ to afford a yellow solid (1.05 g, 51\%). ${ }^{1} \mathrm{H}$ NMR (400 MHz, $\mathrm{CDCl}_{3}$ ), $\delta$ (ppm): 6.93-6.92 $(\mathrm{d}, J=3.7 \mathrm{~Hz}, 2 \mathrm{H}), 6.65-6.64(\mathrm{~d}, J=3.7 \mathrm{~Hz}, 2 \mathrm{H}), 3.91(\mathrm{~s}, 4 \mathrm{H}) .{ }^{13} \mathrm{C}$ $\mathrm{NMR}\left(100 \mathrm{MHz}, \mathrm{CDCl}_{3}\right.$ ), $\delta$ (ppm): 201.47, 135.94, 129.78, 127.53, 111.81, 42.74. FT-IR spectra data: $v_{\mathrm{C}=\mathrm{O}}: 1,698$ and $1,663 \mathrm{~cm}^{-1}$.

\section{Synthesis of BCPONI-2Br}

Under nitrogen, to a mixture of compound 4 (500 mg, $0.85 \mathrm{mmol}$ ), 1,3-bis(4-bromophenyl)-2-propanone (313 mg, 0.85 $\mathrm{mmol})$, and ethanol $(25 \mathrm{~mL}), 24 \mathrm{mg}$ of $\mathrm{KOH}(0.42 \mathrm{mmol})$ in $5 \mathrm{~mL}$ of ethanol were added slowly. The solution changed to red immediately and then precipitates formed gradually. The mixture was refluxed for $30 \mathrm{~min}$ and then cooled down to room temperature. The organic layer was extracted by $\mathrm{CH}_{2} \mathrm{Cl}_{2}$ and dried with anhydrous $\mathrm{MgSO}_{4}$. After removal of the solvent, the crude product was purified by column chromatography on silica gel using a mixed eluent of petroleum ether and $\mathrm{CH}_{2} \mathrm{Cl}_{2}(1: 2$, $\mathrm{v} / \mathrm{v})$ to yield a brown solid (470 mg, 60\%). ${ }^{1} \mathrm{H}$ NMR $(400 \mathrm{MHz}$, $\left.\mathrm{CDCl}_{3}\right), \delta(\mathrm{ppm}): 8.60-8.58(\mathrm{~d}, J=7.6 \mathrm{~Hz}, 2 \mathrm{H}), 8.22-8.20(\mathrm{~d}$, $J=7.6 \mathrm{~Hz}, 2 \mathrm{H}), 7.73(\mathrm{br}, 8 \mathrm{H}), 4.13-4.12(\mathrm{~d}, J=4.0 \mathrm{~Hz}, 2 \mathrm{H})$, 1.98 (br, $1 \mathrm{H}), 1.21(\mathrm{~m}, 40 \mathrm{H}), 0.86(\mathrm{~m}, 6 \mathrm{H}) .{ }^{13} \mathrm{C}$ NMR $(100$ $\mathrm{MHz}, \mathrm{CDCl}_{3}$ ), $\delta$ (ppm): 199.52, 163.35, 151.73, 142.55, 135.34, $132.61,132.23,130.53,128.95,126.73,124.58,124.08,122.56$, $121.34,44.76,36.67,31.95,31.77,30.07,29.69,29.38,26.54,22.71$, 14.14. FT-IR spectra data: $v_{\mathrm{C}=\mathrm{O}}: 1,698$ and $1,663 \mathrm{~cm}^{-1}$. HRMS (MALDI-TOF): $\mathrm{m} / \mathrm{z}[\mathrm{M}]^{+}$calcd for $\left(\mathrm{C}_{53} \mathrm{H}_{62} \mathrm{Br}_{2} \mathrm{NO}_{3}\right)$ : 918.3090; found: 918.3090 .

\section{Synthesis of TCPONI-2Br}

Under nitrogen, to a mixture of compound 4 (500 mg, 0.85 $\mathrm{mmol}$ ), 1,3-bis(5-bromothiophenyl)-2-propanone (324 mg, 0.85 $\mathrm{mmol})$, and ethanol $(25 \mathrm{~mL}), 24 \mathrm{mg}$ of $\mathrm{KOH}(0.42 \mathrm{mmol})$ in $5 \mathrm{~mL}$ of ethanol were added slowly. The red mixture was then refluxed for $30 \mathrm{~min}$. The organic layer was extracted by $\mathrm{CH}_{2} \mathrm{Cl}_{2}$ and dried with anhydrous $\mathrm{MgSO}_{4}$. After filtration and removal of the solvent, the crude product was purified by column chromatography on silica gel using a mixed eluent of petroleum ether and $\mathrm{CH}_{2} \mathrm{Cl}_{2}(1: 2, \mathrm{v} / \mathrm{v})$ to yield a brown solid $(476 \mathrm{mg}, 60 \%)$. ${ }^{1} \mathrm{H}$ NMR (400 MHz, $\mathrm{CDCl}_{3}$ ), $\delta$ (ppm): 8.43-8.41 (d, $J=7.6 \mathrm{~Hz}$, $2 \mathrm{H}), 8.05-8.03(\mathrm{~d}, J=7.7 \mathrm{~Hz}, 2 \mathrm{H}), 7.37-7.36(\mathrm{~d}, J=4.0 \mathrm{~Hz}$, $2 \mathrm{H}), 6.99-6.98$ (d, $J=4.0 \mathrm{~Hz}, 2 \mathrm{H}), 4.10-4.08(\mathrm{~d}, J=7.1 \mathrm{~Hz}, 2 \mathrm{H})$, 1.98 (br, $1 \mathrm{H}), 1.38-1.20(\mathrm{~m}, 40 \mathrm{H}), 0.86(\mathrm{~m}, 6 \mathrm{H}) .{ }^{13} \mathrm{C}$ NMR $(100$ $\left.\mathrm{MHz}, \mathrm{CDCl}_{3}\right), \delta$ (ppm): 197.23, 163.02, 146.76, 141.29, 133.36, $133.24,131.87,130.60,130.04,125.93,122.08,121.80,118.18$, $117.01,36.93,31.98,31.74,30.25,29.76,29.73,29.42,26.50$, $22.73,14.16$. FT-IR spectra data: $v_{\mathrm{C}=\mathrm{O}}: 1,698$ and $1,660 \mathrm{~cm}^{-1}$. HRMS (MALDI-TOF): $\mathrm{m} / \mathrm{z}[\mathrm{M}]^{+}$calcd for $\left(\mathrm{C}_{49} \mathrm{H}_{58} \mathrm{Br}_{2} \mathrm{NO}_{3} \mathrm{~S}_{2}\right)$ : 930.2219; found: 930.2226 .

\section{Synthesis of P1}

Under nitrogen, a mixture of BCPONI-2Br (147 mg, 0.16 mmol), $\quad N$-(2-decyltetradecyl)-2,7-bis-(4,4,5,5-tetramethyl1,3,2-dioxaborolane-2-yl)carbazole (124 $\mathrm{mg}, \quad 0.16 \mathrm{mmol}$ ), $\mathrm{Pd}\left(\mathrm{PPh}_{3}\right)_{2} \mathrm{Cl}_{2}(15 \mathrm{mg})$, chlorobenzene $(5 \mathrm{~mL}), 2 \mathrm{~mL}$ of $\mathrm{Na}_{2} \mathrm{CO}_{3}$ aqueous solution $(2 \mathrm{M})$, and a drop of aliquat 336 was added into a $25 \mathrm{~mL}$ Schlenk tube. The tube was charged with nitrogen through a freeze-pump-thaw cycle for three times. The mixture was stirred at $100^{\circ} \mathrm{C}$ for $5 \mathrm{~h}$ in the absence of light. After cooling to room temperature, the mixture was dropped into a mixed 
solution of methanol $(200 \mathrm{~mL})$ and concentrated hydrochloric acid $(5 \mathrm{~mL})$ and stirred for another $0.5 \mathrm{~h}$. The dark solid was collected and Soxhlet-extracted with ethanol, acetone, hexane, and chlorobenzene. After removal of chlorobenzene, a black solid was obtained (170 mg, 84\%). ${ }^{1} \mathrm{H} \mathrm{NMR} \mathrm{(500} \mathrm{MHz,} \mathrm{C}_{2} \mathrm{D}_{2} \mathrm{Cl}_{4}$, $373 \mathrm{~K}), \delta$ (ppm): 8.70-7.31 (br, 18H), 4.50-4.00 (br, 4H), 2.31 (br, 1H), 2.12 (br, 1H), 1.60-0.70 (m, 92H). FT-IR spectra data: $v_{\mathrm{C}=\mathrm{O}}: 1,699$ and $1,664 \mathrm{~cm}^{-1}$. GPC: $M_{\mathrm{n}}=7.47 \mathrm{kDa}, M_{\mathrm{w}}=24.12$ $\mathrm{kDa}, \mathrm{PDI}=3.23$.

\section{Synthesis of P2}

Under nitrogen, a mixture of BCPONI-2Br (147 mg, 0.16 mmol), 2,6-bis(trimethyltin)-4,8-di(2-hexyl)decyloxybenzo[1,2$\left.b ; 3,4-b^{\prime}\right]$ dithiophene (177 $\left.\mathrm{mg}, 0.16 \mathrm{mmol}\right), \mathrm{Pd}_{2}(\mathrm{dba})_{3}(9 \mathrm{mg})$, $\mathrm{P}(\mathrm{o}-\mathrm{tol})_{3}(15 \mathrm{mg})$, and anhydrous chlorobenzene $(5 \mathrm{~mL})$ was added into a $25 \mathrm{~mL}$ Schlenk tube. The tube was subsequently charged with nitrogen through a freeze-pump-thaw cycle for three times. The mixture was heated to $120^{\circ} \mathrm{C}$ and stirred for $60 \mathrm{~h}$ in the absence of light. After cooling to room temperature, the mixture was dropped into a mixed solution of methanol $(200 \mathrm{~mL})$ and concentrated hydrochloric acid $(5 \mathrm{~mL})$ and stirred for another $0.5 \mathrm{~h}$. The black solid was collected and further Soxhletextracted with ethanol, acetone, hexane, and chlorobenzene. After removal of chlorobenzene, $\mathrm{P} 2$ was obtained as a black solid (227 mg, 92\%). ${ }^{1} \mathrm{H}$ NMR (500 MHz, $\left.\mathrm{C}_{2} \mathrm{D}_{2} \mathrm{Cl}_{4}, 373 \mathrm{~K}\right), \delta$ (ppm): 8.70-7.50 (br, 14H), 4.50-4.00 (br, 6H), 2.20-2.00 (m, 3H), 2.00$0.70(\mathrm{~m}, 122 \mathrm{H})$. FT-IR spectra data: $v_{\mathrm{C}=\mathrm{O}}: 1,700$ and $1,666 \mathrm{~cm}^{-1}$. GPC: $M_{\mathrm{n}}=55.31 \mathrm{kDa}, M_{\mathrm{w}}=75.67 \mathrm{kDa}, \mathrm{PDI}=1.37$.

\section{Synthesis of P3}

A mixture of BCPONI-2Br (147 mg, $0.16 \mathrm{mmol}), 2,6-$ bis(trimethylstannyl)- $N$-(2-decyltetradecyl)-dithieno[3,2-

$\left.b: 2^{\prime}, 3^{\prime}-d\right]$ pyrrole (135 mg, $\left.0.16 \mathrm{mmol}\right), \mathrm{Pd}_{2}(\mathrm{dba})_{3} \quad(9 \mathrm{mg})$, $\mathrm{P}(o \text {-tol })_{3}(15 \mathrm{mg})$, and anhydrous chlorobenzene $(5 \mathrm{~mL})$ was added to a $25 \mathrm{~mL}$ Schlenk tube. The tube was then charged with nitrogen through a freeze-pump-thaw cycle for three times. The mixture was heated to $115^{\circ} \mathrm{C}$ and stirred for $72 \mathrm{~h}$ under nitrogen atmosphere. After cooling to room temperature, the mixture was dropped into a mixed solution of methanol $(200 \mathrm{~mL})$ and concentrated hydrochloric acid $(5 \mathrm{~mL})$ and stirred for another $0.5 \mathrm{~h}$. The solid product was collected and Soxhlet-extracted with ethanol, acetone, hexane, and chlorobenzene. After removal of chlorobenzene, a black solid was obtained (188 mg, 92\%). ${ }^{1} \mathrm{H}$ NMR (500 MHz, $\mathrm{C}_{2} \mathrm{D}_{2} \mathrm{Cl}_{4}, 373 \mathrm{~K}$ ), $\delta$ (ppm): 8.70-7.00 (br, $14 \mathrm{H}$ ), 4.50-3.70 (br, 4H), 2.18-2.04 (br, 2H), 1.70-0.70 (m, 92H). FT-IR spectra data: $v_{\mathrm{C}=\mathrm{O}}: 1,697$ and $1,662 \mathrm{~cm}^{-1}$. GPC: $M_{\mathrm{n}}=23.50$ $\mathrm{kDa}, M_{\mathrm{w}}=45.82 \mathrm{kDa}, \mathrm{PDI}=1.95$.

\section{Synthesis of P4}

A mixture of TCPONI-2Br (149 mg, 0.16 mmol), $N$-(2-decyltetradecyl)-2,7-bis-(4,4,5,5-tetramethyl-1,3,2-

dioxaborolane-2-yl)carbazole (124 mg, $0.16 \mathrm{mmol}$ ), $\mathrm{Pd}\left(\mathrm{PPh}_{3}\right)_{2} \mathrm{Cl}_{2}(15 \mathrm{mg})$, chlorobenzene $(5 \mathrm{~mL}), 2 \mathrm{~mL}$ of $\mathrm{Na}_{2} \mathrm{CO}_{3}$ aqueous solution $(2 \mathrm{M})$, and a drop of aliquat 336 was added to a $25 \mathrm{~mL}$ Schlenk tube. The tube was then charged with nitrogen through a freeze-pump-thaw cycle for three times. The mixture was stirred at $100^{\circ} \mathrm{C}$ for $5 \mathrm{~h}$ under nitrogen atmosphere. After cooling to room temperature, the mixture was dropped into a mixed solution of methanol $(200 \mathrm{~mL})$ and concentrated hydrochloric acid $(5 \mathrm{~mL})$ and stirred for another $0.5 \mathrm{~h}$. The crude product was collected and Soxhlet-extracted with ethanol, acetone, hexane, and chlorobenzene. After removal of chlorobenzene, $\mathrm{P} 4$ was obtained as a black solid $(171 \mathrm{mg}$, 84\%). ${ }^{1} \mathrm{H}$ NMR (500 MHz, $\mathrm{C}_{2} \mathrm{D}_{2} \mathrm{Cl}_{4}, 373 \mathrm{~K}$ ), $\delta$ (ppm): 9.00-6.50 (br, 14H), 4.50-3.80 (br, 4H), 2.00-0.60 (m, 94H). FT-IR spectra data: $v_{\mathrm{C}=\mathrm{O}}: 1,697$ and $1,660 \mathrm{~cm}^{-1}$. GPC: $M_{\mathrm{n}}=20.10 \mathrm{kDa}, M_{\mathrm{w}}$ $=40.41 \mathrm{kDa}, \mathrm{PDI}=2.01$.

\section{Synthesis of P5}

A mixture of TCPONI-2Br (149 mg, $0.16 \mathrm{mmol}), 2,6-$ bis(trimethyltin)-4,8-di(2-hexyl)decyloxybenzo[1,2- $b ; 3,4$ -

$b^{\prime}$ ]dithiophene (177 mg, $\left.0.16 \mathrm{mmol}\right), \mathrm{Pd}_{2}(\mathrm{dba})_{3}(9 \mathrm{mg}), \mathrm{P}(\mathrm{o}-\mathrm{tol})_{3}$ $(15 \mathrm{mg})$, and anhydrous chlorobenzene $(5 \mathrm{~mL})$ was added to a $25 \mathrm{~mL}$ Schlenk tube. The mixture was charged with nitrogen through a freeze-pump-thaw cycle for three times and then stirred at $110^{\circ} \mathrm{C}$ for $3 \mathrm{~h}$ in the absence of light. After cooling to room temperature, the mixture was dropped into a mixed solution of methanol $(200 \mathrm{~mL})$ and concentrated hydrochloric acid $(5 \mathrm{~mL})$ and stirred for another $0.5 \mathrm{~h}$. The solid product was collected and Soxhlet-extracted with ethanol, acetone, hexane, and chlorobenzene. After removal of chlorobenzene, a black solid was obtained (239 mg, 96\%). ${ }^{1} \mathrm{H}$ NMR $(500 \mathrm{MHz}$, $\left.\mathrm{C}_{2} \mathrm{D}_{2} \mathrm{Cl}_{4}, 373 \mathrm{~K}\right), \delta$ (ppm): 9.00-6.50 (br, $\left.10 \mathrm{H}\right), \quad 4.60-3.80$ (br, $6 \mathrm{H}), 2.50-0.60(\mathrm{~m}, 125 \mathrm{H})$. FT-IR spectra data: $v_{\mathrm{C}=\mathrm{O}}$ : 1,698 and $1,662 \mathrm{~cm}^{-1}$. GPC: $M_{\mathrm{n}}=32.21 \mathrm{kDa}, M_{\mathrm{w}}=77.10$ $\mathrm{kDa}, \mathrm{PDI}=2.40$.

\section{Synthesis of P6}

A mixture of TCPONI-2Br (149 mg, $0.16 \mathrm{mmol})$, 2,6bis(trimethylstannyl)-N-(2-decyltetradecyl)-dithieno[3,2-

$\left.b: 2^{\prime}, 3^{\prime}-d\right]$ pyrrole (135 mg, $\left.0.16 \mathrm{mmol}\right), \mathrm{Pd}_{2}(\mathrm{dba})_{3} \quad(9 \mathrm{mg})$, $\mathrm{P}(\mathrm{o} \text {-tol })_{3}(15 \mathrm{mg})$, and anhydrous chlorobenzene $(5 \mathrm{~mL})$ was added to a $25 \mathrm{~mL}$ Schlenk tube. The mixture was charged with nitrogen through a freeze-pump-thaw cycle for three times and then stirred at $115^{\circ} \mathrm{C}$ for $24 \mathrm{~h}$ in the absence of light. After cooling to room temperature, the mixture was dropped into a mixed solution of methanol $(200 \mathrm{~mL})$ and concentrated hydrochloric acid $(5 \mathrm{~mL})$ and stirred for another $0.5 \mathrm{~h}$. The solid product was collected and Soxhlet-extracted with ethanol, acetone, hexane, and chlorobenzene. After removal of chlorobenzene, a black solid was obtained (196 mg, 95\%). ${ }^{1} \mathrm{H}$ NMR $(500 \mathrm{MHz}$, $\left.\mathrm{C}_{2} \mathrm{D}_{2} \mathrm{Cl}_{4}, 373 \mathrm{~K}\right), \delta$ (ppm): 8.00-6.40 (br, $\left.10 \mathrm{H}\right), 4.50-3.60$ (br, $4 \mathrm{H}), 2.40-0.50(\mathrm{~m}, 94 \mathrm{H})$. FT-IR spectra data: $v_{\mathrm{C}=\mathrm{O}}: 1,696$ and $1,660 \mathrm{~cm}^{-1}$. GPC: $M_{\mathrm{n}}=7.06 \mathrm{kDa}, M_{\mathrm{w}}=16.49 \mathrm{kDa}, \mathrm{PDI}=2.34$.

\section{RESULTS AND DISCUSSION}

\section{Synthesis}

Figure 3 describes the synthetic routes of the two CPONIcontaining monomers and their D-A copolymers. Two important intermediates, 1,3-dithiophenyl-2-propanone (1) (Walker et al., 2008) and 1,3-bis(4-bromophenyl)-2-propanone (3) (Walker et al., 2008), were synthesized according to the reported procedures, respectively. The synthesis of both 

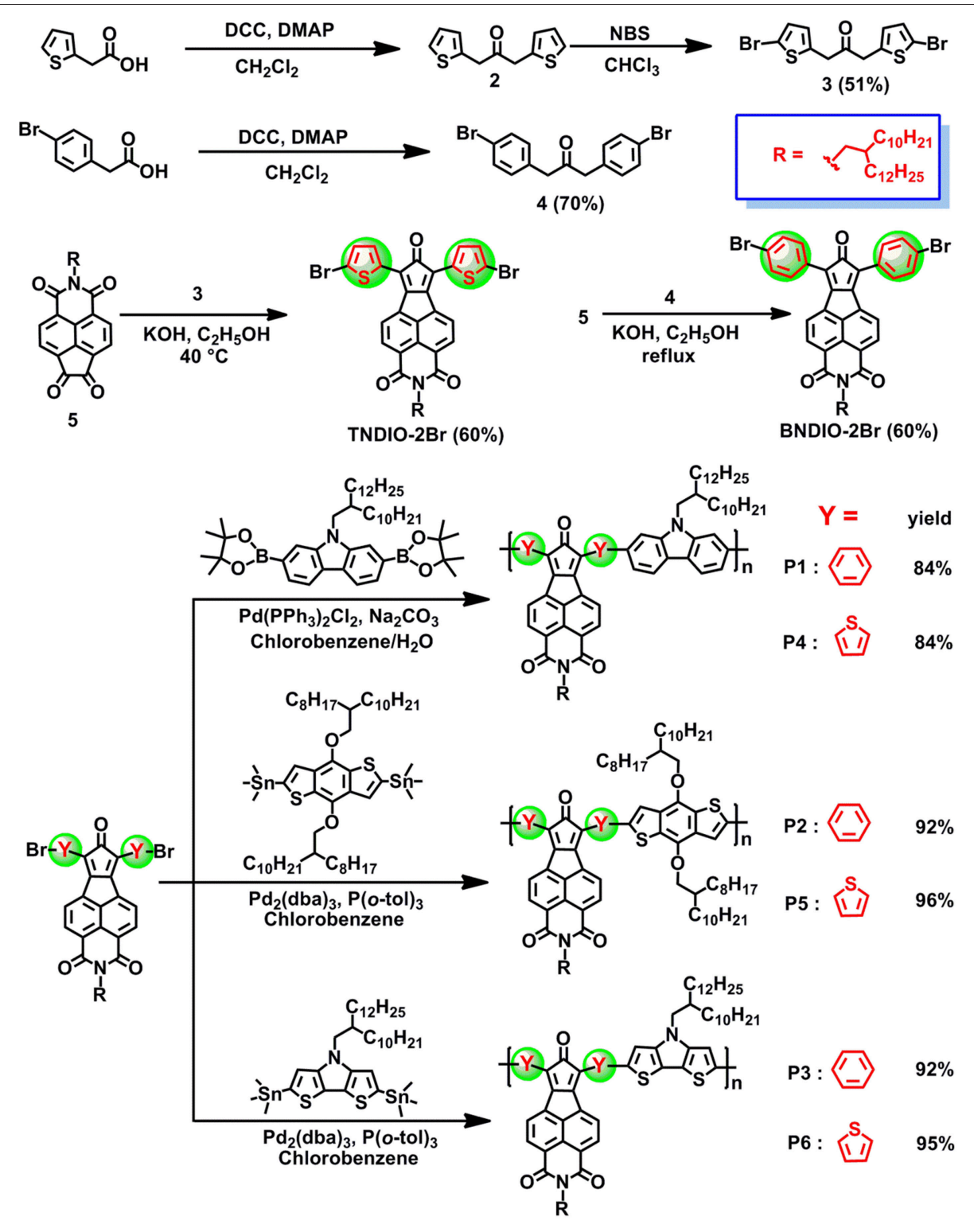

FIGURE 3 | Synthetic route for the CPONI-based monomers and their copolymers.

monomers started from the self-condensation reactions of thiopheneacetic acid or 4-bromobenzeneacetic acid to give compounds 1 and 3, respectively. Then, bromination of compound 1 with NBS afforded 1,3-bis(5-bromothiophenyl)2 -propanone (2) in 51\% yields. Finally, double Knoevenagel condensation reactions were readily performed between diketone-containing 5 and compounds 1 or 3 to produce two black solids, BCPONI-2Br and TCPONI-2Br, respectively. The chemical structures of all the intermediates and dibrominated monomers were confirmed by ${ }^{1} \mathrm{H}$ NMR and ${ }^{13} \mathrm{C} \quad \mathrm{NMR}$ (Figures S11-S16). In addition, the diboronicester reagent of carbazole (Kim et al., 2011), as well as distannyl derivatives of benzodithiophene (Mei et al., 2013) and dithienopyrrole (Zhang et al., 2010), were prepared according to similar literature procedures, and their ${ }^{1} \mathrm{H}$ NMR data are provided in Figures S17-S19.

The target copolymers were synthesized via the standard palladium-catalyzed Suzuki or Stille coupling reaction between the dibrominated monomers (BCPONI-2Br and TCPONI-2Br) and electron-donated monomers (carbazole, benzodithiophene, and dithienopyrrole). For benzodithiopheneand dithienopyrrole-containing polymers (P2, P3, P5, and $\mathrm{P} 6)$, Stille polymerization was conducted using $\mathrm{Pd}_{2}(\mathrm{dba})_{3} / \mathrm{P}(o-$ tol $)_{3}$ as the catalyst, while $\mathrm{P} 1$ and $\mathrm{P} 4$ was synthesized by $\mathrm{Pd}(\mathrm{PPh})_{2} \mathrm{Cl}_{2}$-catalyzed Suzuki polymerization. In fact, when we chose $\mathrm{Pd}_{2}(\mathrm{dba})_{3} / \mathrm{P}(o \text {-tol })_{3}$ as the catalyst, all the resulted $\mathrm{P} 1$ and P4 samples were insoluble due to "over-polymerization." Fortunately, we obtained all the solution-processable polymer 
TABLE 1 | Molecular weight, yield, and decomposition temperature of the polymers.

\begin{tabular}{|c|c|c|c|c|c|}
\hline \multirow[t]{2}{*}{ Polymer } & \multirow{2}{*}{$\begin{array}{c}\text { Yield } \\
(\%)\end{array}$} & \multirow{2}{*}{$\begin{array}{c}M_{\mathrm{n}} \\
(\mathrm{kDa})\end{array}$} & \multirow{2}{*}{$\frac{M_{\mathrm{w}}}{\text { (kDa) }}$} & \multirow[t]{2}{*}{ PDI } & \multirow{2}{*}{$\frac{T_{\mathrm{d}}}{\left({ }^{\circ} \mathrm{C}\right)}$} \\
\hline & & & & & \\
\hline P1 & 84 & 7.47 & 24.12 & 3.23 & 405 \\
\hline P2 & 92 & 55.31 & 75.67 & 1.37 & 344 \\
\hline P3 & 92 & 23.50 & 45.82 & 1.95 & 412 \\
\hline P4 & 84 & 20.10 & 40.41 & 2.01 & 429 \\
\hline P5 & 96 & 32.21 & 77.10 & 2.40 & 351 \\
\hline P6 & 95 & 7.06 & 16.49 & 2.34 & 413 \\
\hline
\end{tabular}

samples (P1-P6) that can be dissolved in warm organic solvents (chloroform, chlorobenzene, and xylene).

Molecular weight of the polymers was measured by hightemperature $\left(150^{\circ} \mathrm{C}\right) \mathrm{GPC}$ and calibrated by monodisperse polystyrene. The observed number-average molecular weights $\left(M_{\mathrm{n}}\right)$ are $7.06-55.31 \mathrm{kDa}$, and the polydispersity indices are 1.373.23 (Table 1 and Figures S1-S6). The thermal properties of the polymers were investigated by TGA and DSC instruments under nitrogen. As seen from Figure 4, all the polymers display excellent thermal stability. For the carbazole- and dithienopyrrole-containing polymers (P1, P3, P4, and P6), the thermal decomposition temperature $\left(T_{\mathrm{d}}\right)$ at $5 \%$ weight loss are above $398^{\circ} \mathrm{C}$, while the benzodithiophene-containing P2 and P5 exhibit much lower $T_{\mathrm{d}}\left(\mathrm{ca} .350^{\circ} \mathrm{C}\right)$. Additionally, no obvious phase transition was detected from the DSC measurements during the heating/cooling scan between room temperature and $280^{\circ} \mathrm{C}$ (Figure S7). FT-IR spectroscopy of the polymers displays typical characteristic bands $\left(v_{\mathrm{C}=\mathrm{O}}\right)$ at ca. 1,697 and $1,660 \mathrm{~cm}^{-1}$, thereby providing direct evidence for the carbonyl groups in the polymers (Figures S8, S9). Although ${ }^{1} \mathrm{H}$ NMR spectroscopy of the polymers were collected at a high temperature of $373 \mathrm{~K}$, only broad and featureless signals were detected at aromatic $(\delta=7.0-9.0 \mathrm{ppm})$ and alkyl bands $(\delta=3.5-4.5$ and $0.5-2.5 \mathrm{ppm}$ ) (Figures S20-S25). The results suggest that a common phenomenon, i.e., strong interchain aggregation (Guo and Watson, 2011), also exists in the newly-developed CPONI-containing polymers and cannot be broken even at high temperature of $373 \mathrm{~K}$.

\section{Optical Properties}

UV-vis-NIR absorption spectra of the CPONI-containing monomers and their D-A polymers were recorded in chloroform (ca. $10^{-5} \mathrm{M}$ ) and in spin-coated thin films (Table 2 and Table S1). As seen from Figure 5A, the absorption spectrum of the BCPONI-2Br solution covers the whole UV-vis band, while the one of TCPONI-2Br is further extended to the NIR band, as far as $850 \mathrm{~nm}$. The maximum absorption peak of the TCPONI$2 \mathrm{Br}$ solution is $532 \mathrm{~nm}$, which exhibits a $46 \mathrm{~nm}$ red-shift compared with BCPONI-2Br (Figures 5A and Table S1). This bathochromic shift can be ascribed to the enhanced coplanarity and stronger D-A intramolecular interaction between richelectron thipohene and CPONI moieties. Interestingly, the overwhelmingly electron-deficient feature of the central CPONI

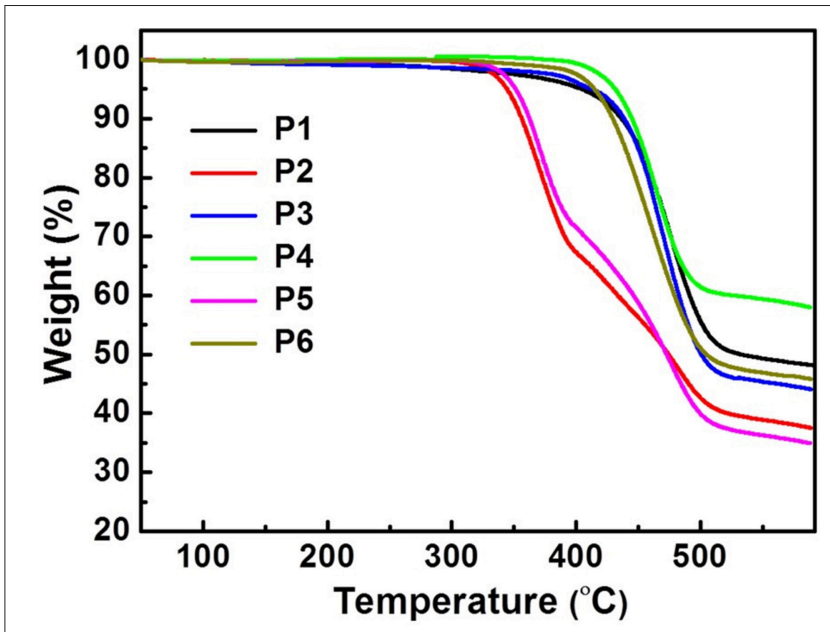

FIGURE 4 | TGA curves of the CPONI-based polymers.

acceptor unit endows BCPONI-2Br and TCPONI-2Br with remarkably extended absorption onsets when compared with the well-known acceptor building blocks, such as DPPT-2Br (Gao et al., 2015) and NDIT-2Br (Senkovskyy et al., 2011) (Figures 5A,B). In comparison with solution spectra, both BCPONI-2Br and TCPONI-2Br thin films exhibit much broader absorption bands, with the maximum absorption onsets of ca. 750 and $950 \mathrm{~nm}$, respectively. All these results indicate a strong solid-state aggregation or interchain organization, generally associated with high-mobility charge carrier transport (Zhu et al., 2017).

Due to the strong D-A intramolecular interactions (Zhu et al., 2017), all polymers achieve ultra-broadband absorption from UV to NIR (Figures 5C,D). Moreover, three typical absorption bands, corresponding to $\pi-\pi^{*}$ transition (ca. $350-500 \mathrm{~nm}$ ) and charge transfer (ca. 500-1,600 nm), were clearly observed in both solution and thin-film spectra. For TCPONI-based polymers, the maximum absorption peaks were $408 \mathrm{~nm}$ for P4, $440 \mathrm{~nm}$ for P5, and $475 \mathrm{~nm}$ for P6 (Table 2). Compared with TCPONI-containing analogs, three BCPONI-based polymers exhibit relatively narrower light-capturing bands and sharply blue-shifted $\pi-\pi^{*}$ transition peaks, which could be explained by the strong backbone twisting and weak electron-donating ability of benzene moieties. In thin film, the $\pi-\pi^{*}$ transition peaks for all polymers display a slight (ca. 2-6 nm) red-shift, while the maximum absorption edges were blue-shifted by ca. 4-56 nm (Table 2), indicative of a more planar conformation in their solid-state films (Zhu et al., 2017). Accordingly, all these observations reveal that the absorption and $E_{\mathrm{g}}^{\text {opt }}$ of the BCPONI- and TCPONI-containing polymers can be finetuned by choosing different donors and $\pi$-conjugation linkers. Moreover, the absorption wavelength can be extended easily by increasing the electron-donating ability of the donor units. On the basis of the absorption onsets of polymer films, the $E_{\mathrm{g}}^{\mathrm{opt}}$ values were determined to be $1.55 \mathrm{eV}$ for P1, $1.44 \mathrm{eV}$ for P2, $1.20 \mathrm{eV}$ for P3, $1.07 \mathrm{eV}$ for P4, $1.06 \mathrm{eV}$ for P5, and 0.81 for P6. Notably, such ultralow $E_{\mathrm{g}}^{\mathrm{opt}} \approx 0.81$ observed here suggests that P6 has a highly 
TABLE 2 | Photophysical and electrochemical properties of the Polymers.

\begin{tabular}{|c|c|c|c|c|c|c|c|c|c|c|}
\hline \multirow[t]{2}{*}{ Polymer } & $\lambda_{\max }^{\text {sol }}$ & $\lambda_{\text {onset }}^{\text {sol }}$ & $\lambda_{\max }^{f i l m}$ & $\lambda_{\text {onset }}^{\text {film }}$ & $\Delta E_{g}^{o p t ~ a ~}$ & $E_{\text {HOMо }}$ & $E_{\text {onset }^{\text {ox }}}^{o x}$ & $E_{L U M O}$ & $E_{\text {onset }^{b}}^{\text {red }}$ & $\Delta E_{g}^{c v}$ \\
\hline & $(\mathrm{nm})$ & $(\mathrm{nm})$ & $(\mathrm{nm})$ & $(\mathrm{nm})$ & $(\mathrm{eV})$ & $(e V)$ & (V) & $(\mathrm{eV})$ & (V) & $(\mathrm{eV})$ \\
\hline P1 & 330 & 762 & 338 & 798 & 1.55 & -5.78 & 1.36 & -3.79 & -0.63 & 1.99 \\
\hline P2 & 389 & 863 & 390 & 860 & 1.44 & -5.34 & 0.92 & -3.77 & -0.65 & 1.57 \\
\hline P3 & 408 & 1,088 & 410 & 1,032 & 1.20 & -5.12 & 0.70 & -3.76 & -0.66 & 1.36 \\
\hline P4 & 408 & 1,174 & 414 & 1,152 & 1.07 & -5.43 & 1.01 & -3.88 & -0.54 & 1.55 \\
\hline P5 & 440 & 1,196 & 444 & 1,164 & 1.06 & -5.40 & 0.98 & -3.88 & -0.54 & 1.52 \\
\hline P6 & 475 & 1,534 & 481 & 1,530 & 0.81 & -4.96 & 0.54 & -3.86 & -0.56 & 1.10 \\
\hline
\end{tabular}

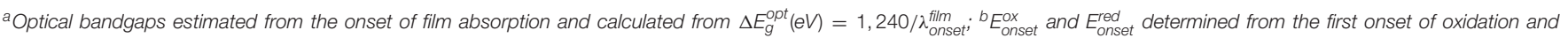
reduction potentials, respectively.
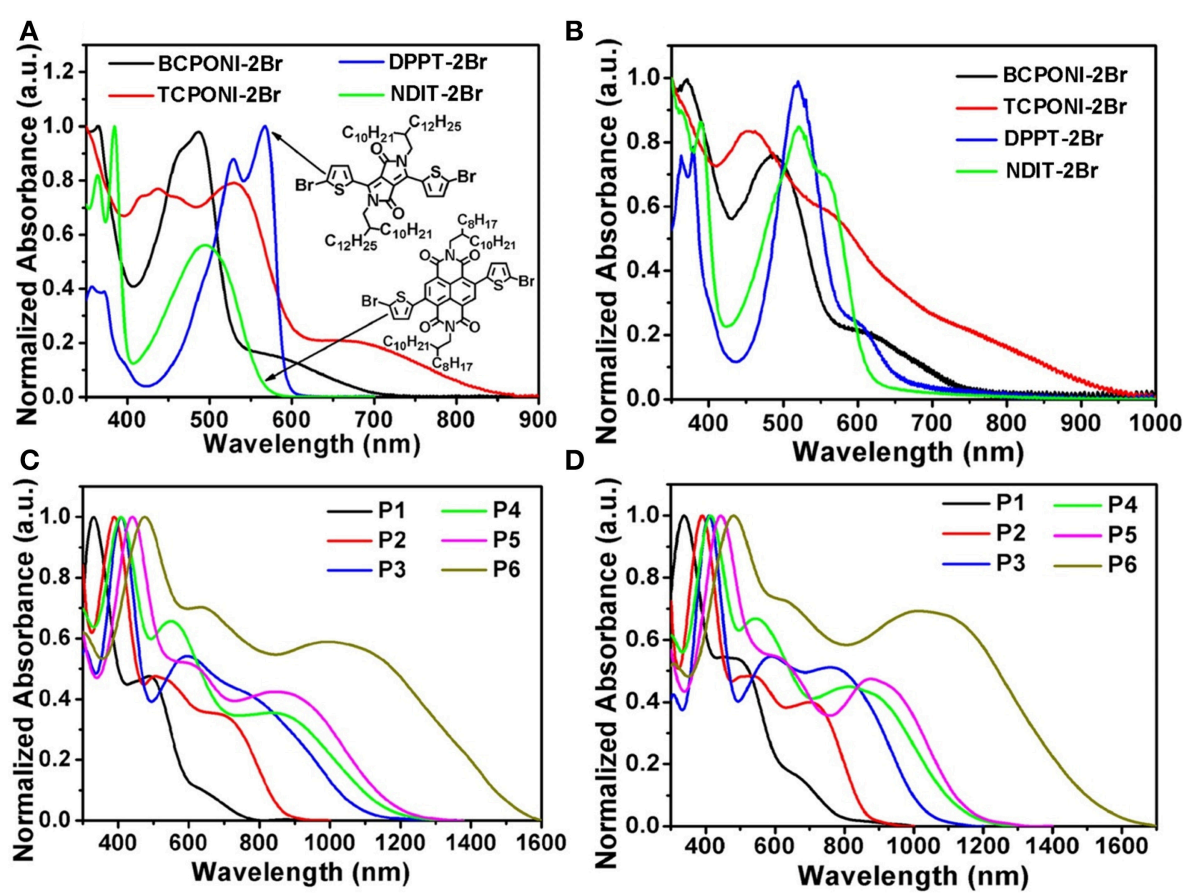

FIGURE 5 | Absorption spectra of the monomers (BCPONI-2Br and TCPONI-2Br), their analogs (DPPT-2Br and NDIT-2Br), and as-synthesized polymers that measured in chloroform solution (A,C) and in thin film (B,D).

delocalization of the $\pi$-electrons, which can be associated with good backbone coplanarity, large $\pi$-conjugation, and strong $\mathrm{D}$-A interaction between donor and CPONI acceptor moieties (Chen et al., 2012; Zhu et al., 2017).

\section{Electrochemical Properties}

To evaluate the electrochemical properties of the CPONIcontaining monomers and their D-A polymers, CV measurements were performed in both dichloromethane solution and thin film. Detailed CV data are provided in Table 2, Table S1, and Figure 6. The $E_{\mathrm{HOMO}}$ and $E_{\mathrm{LUMO}}$ levels are calculated from the onset oxidation $\left(E_{\text {onset }}^{\text {ox }}\right)$ and reduction $\left(E_{\text {onset }}^{\text {red }}\right)$ potentials using the following equations: $E_{\mathrm{HOMO}}=$ $-\left(E_{\text {onset }}^{\text {ox }}+4.42\right)(\mathrm{eV})$ and $E_{\mathrm{LUMO}}=-\left(E_{\text {onset }}^{\text {red }}+4.42\right)(\mathrm{eV})$, which is calibrated by ferrocene/ferrocenium $\left(\mathrm{Fc} / \mathrm{Fc}^{+}\right)$couple
(0.38 V vs. Ag/AgCl) (Chen et al., 2012; Zhu et al., 2017). During positive and negative scans, reversible oxidation, and reduction processes were observed for TCPONI-2Br, while only reduction processes show a reversible feature for $\mathrm{BCPONI}-2 \mathrm{Br}$ (Figure 6A). The calculated LUMO and HOMO energy levels of $\mathrm{BCPONI}-2 \mathrm{Br}$ are -3.87 and $-5.79 \mathrm{eV}$, respectively. In comparison with benzene-flanked BCPONI-2Br, thiopheneflanked TCPONI-2Br exhibits a reduced LUMO energy level $(-4.02 \mathrm{eV})$ but an elevated HOMO energy level $(-5.63 \mathrm{eV})$, owing to enhanced molecular coplanarity as well as improved electron-donating ability of thiophene units (Cui and Wudl, 2013). Surprisingly, much deeper LUMO energy levels for both monomers are observed than that of the previously reported acceptor unit DPPT-2Br (LUMO $=-3.34 \mathrm{eV})(\mathrm{GaO}$ et al., 2015), and are even comparable to the classical $n$-type 

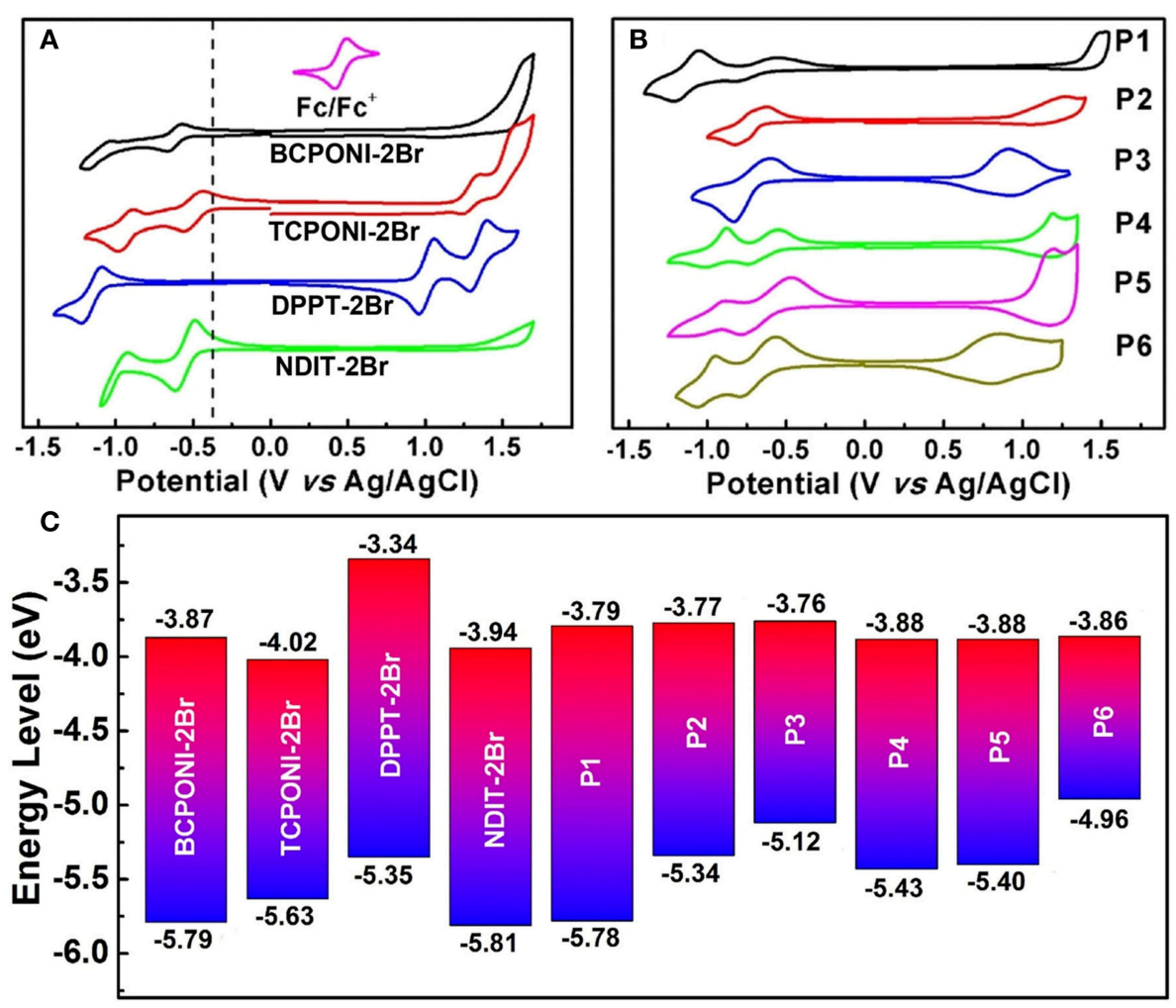

FIGURE 6 | (A) CV curves of the monomers (BCPONI-2Br and TCPONI-2Br), their analogs (DPPT-2Br and NDIT-2Br). (B) CV curves of the polymers. (C) Comparative diagram for the $\mathrm{HOMO}$ and LUMO energy levels.

building block NDIT-2Br (LUMO $=-3.94 \mathrm{eV}$ ) (Senkovskyy et al., 2011). These results suggest that BCPONI-2Br and TCPONI-2Br are very strong acceptor units, which exhibits great potential in construction of various organic/polymeric electron-transporting materials.

All the polymers P1-P6 exhibit strong and reversible oxidation and reduction processes (Figure 6B). The LUMO energy levels of P1-P6, estimated from $E_{\text {onset }}^{\text {red }}$, are $-3.79 \mathrm{eV}$ for $\mathrm{P} 1,-3.77 \mathrm{eV}$ for $\mathrm{P} 2,-3.76 \mathrm{eV}$ for $\mathrm{P} 3,-3.88 \mathrm{eV}$ for $\mathrm{P} 4$, $-3.88 \mathrm{eV}$ for $\mathrm{P} 5$, and $-3.86 \mathrm{eV}$ for P6. As to two type of polymers, their LUMO energy levels show a negligible change with the enhancement of the electron-donating capability of the donor units, while they can be directly influenced by the $\pi$-conjugation linkers of both BCPONI-2Br and TCPONI-2Br monomers; therefore, the thiophene-flanked P4-P6 show slightly reduced LUMO energy levels relative to the benzene-flanked analogs (P1-P3). It was found that the HOMO energy levels and band gaps of the polymers can be readily tuned by the selection of different donors. With increasing donor strength, the HOMO energy levels of the polymers will be upshifted, which caused a reduced band gap. Additionally, the electrochemical band gaps $\left(E_{\mathrm{g}}^{\mathrm{cv}}\right)$ determined here are ca. $0.13-0.48 \mathrm{eV}$ higher than those of their $E_{\mathrm{g}}^{\text {opt }}$. Such a small difference between $E_{\mathrm{g}}^{\mathrm{cv}}$ and $E_{\mathrm{g}}^{\mathrm{opt}}$ has been reported in many studies (Cui and Wudl, 2013 and Chen et al., 2016) and can be explained by the exciton binding energy of the $\pi$-conjugated polymers (Sariciftci, 1997).

\section{OFET Performance and Film Organization}

To demonstrate the application potential of the CPONI-based polymers in OFETs, $\mathrm{P} 5$ was chosen as an example to fabricate polymer FET devices due to its good backbone coplanarity, proper HOMO/LUMO energy levels, good solubility, and high molecular weight. For the optimization of charge carrier transport performance, both bottom-gate/bottom-contact (BG/BC) and top-gate/bottom-contact (TG/BC) device configurations were used to fabricate polymeric FETs. The detailed device fabrication procedures can be found in the supporting information. Under ambient conditions, P5-based BG/BC OFETs exhibited a typical $p$-type transport characteristic with a moderately high hole mobility of $0.02 \mathrm{~cm}^{2} \mathrm{~V}^{-1} \mathrm{~s}^{-1}$ and current on/off ratio $>10^{4}$, while only weak electron transport can be observed in both transfer and output curves (Figures 7A,B). Considering that the LUMO value $(-3.88 \mathrm{eV})$ of $\mathrm{P} 5$ is far from the requirement of thermodynamic stabile electron transport, electrons can be readily captured by $\mathrm{H}_{2} \mathrm{O} / \mathrm{O}_{2}$ in air (Zhan et al., 2011 and Chen et al., 2013). Therefore, only strong hole transport were observed in the P5-based BG/BC OFETs. Due to an effective encapsulation effect of the dielectric layer in TG/BC OFET devices, P5 exhibited an obvious ambipolar transport behavior with both $p$ - and $n$-type operation modes for negative and positive gate voltages, respectively. The saturation mobilities were determined to be $4.11 \times 10^{-3} \mathrm{~cm}^{2} \mathrm{~V}^{-1} \mathrm{~s}^{-1}$ for holes and $5.15 \times 10^{-4} \mathrm{~cm}^{2} \mathrm{~V}^{-1} \mathrm{~s}^{-1}$ for electrons (Figures 7C-F). 

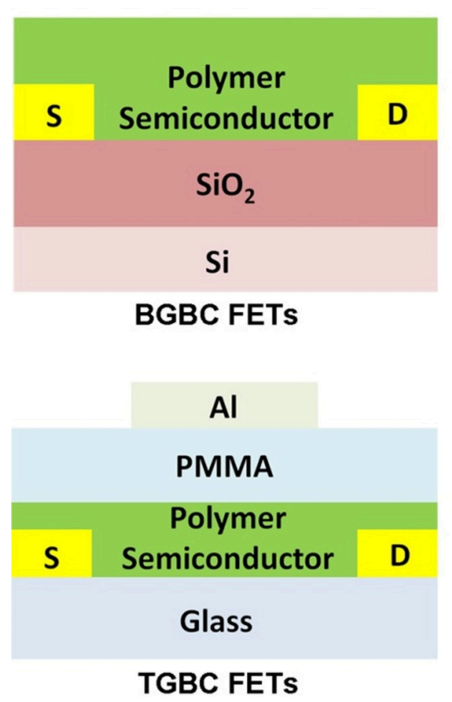
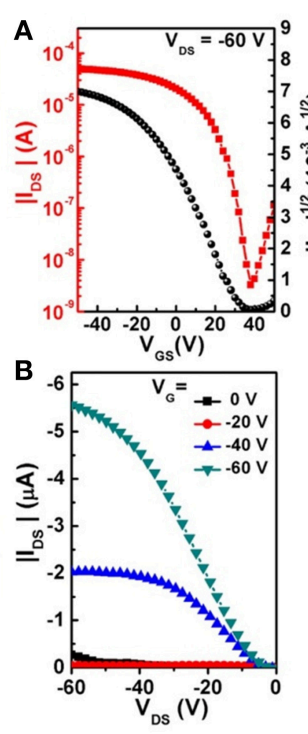
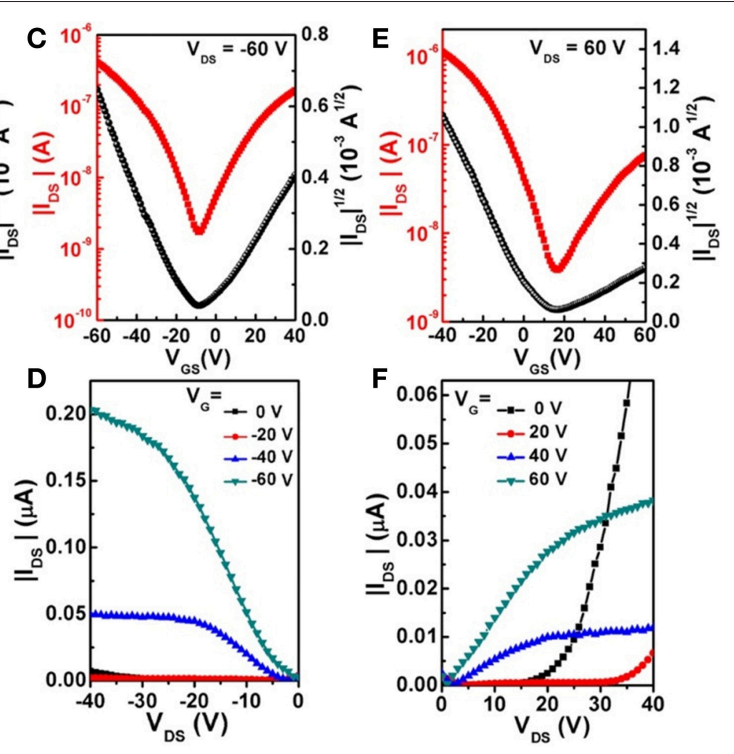

FIGURE 7 | (A) Transfer and (B) output curves of the BGBC OFET devices. (C,E) Transfer and (D,F) output curves of the TGBC OFET devices.

The observed hole and electron mobilities are sufficient for charge carrier transport in potential OPV devices, especially in all-polymer OPVs (Cui and Wudl, 2013). The findings presented above suggest that BCPONI-2Br and TCPONI-2Br are promising building blocks for the construction of polymer electron-transporting materials with attractive electronic properties. To further characterize film organization and surface morphology, AFM and GIXRD measurements were conducted. As seen from Figure S10A, the $\pi-\pi$ stacking reflection (010) are clearly observed in the $q_{z}$ direction, indicative of a primarily faceon model packing for the P5 film. This type of stacking model is consistent with the classical NDI-based polymers such as N2200 (Yan et al., 2009). The calculated lamellar stacking distance and $\pi-\pi$ stacking distance are around 29.11 and $3.79 \AA$, which were determined from the (100) and (010) peaks, respectively. Furthermore, P5 film shows a smooth surface microscopy and a very small root-mean-square surface roughness of $0.82 \mathrm{~nm}$ (Figure S10B), which is helpful for good interface contact between polymer film and dielectric layer (Zhu et al., 2017).

\section{CONCLUSIONS}

We have designed and synthesized two novel aromatic imides, diarylcyclopentadienone-fused naphthalimides (BCPONI-2Br and TCPONI-2Br), in which a five-membered cyclopentadienone unit is fused at the lateral position of the naphthalimide skeleton. Compared with both well-known DPPT-2Br and NDIT-2Br building blocks, BCPONI-2Br and TCPONI-2Br exhibit extended absorption bands, narrower band gaps, and even lower LUMO levels, as low as $-4.02 \mathrm{eV}$. Such deep-lying LUMO values enable them to function as the strong acceptors. Furthermore, Stille and Suzuki polycondensation between both novel acceptors and different donors (carbazole, benzodithiophene, and dithienopyrrole) was performed to afford six novel D-A polymers (P1-P6). It was found that optical and electrochemical properties of the polymers are finetuned by the variations of donors and $\pi$-conjugation linkers. Compared with the BCPONI-containing analogs (P1-P3), the TCPONI-containing P4-P6 exhibit extended absorption bands and deeper LUMO energy levels due to more electron-rich thiophene and more planar $\pi$-conjugation skeleton. With an increasing electron-donating ability of the donor units, an extended NIR absorption and an upshifted HOMO levels were observed clearly, while LUMO levels were almost unaffected. The estimated LUMO levels were as low as $-3.88 \mathrm{eV}$, indicating very strong electron affinities for these polymers. Preliminary OFETs results show that $\mathrm{P} 5$ exhibits a moderately high hole mobility of $0.02 \mathrm{~cm}^{2} \mathrm{~V}^{-1} \mathrm{~s}^{-1}$ in BGBC OFETs and a typical ambipolar transport behavior in TGBC OFETs. All these observed results suggest that $\mathrm{BCPONI}-2 \mathrm{Br}$ and $\mathrm{TCPONI}-2 \mathrm{Br}$ units are very strong and interesting acceptor building blocks for the creation of various low bandgap $\pi$-conjugated materials, especially for electron-transporting polymers. These polymers could be functioned as the electron acceptor materials in all-polymer solar cells or other optoelectronic devices.

\section{DATA AVAILABILITY}

All datasets generated for this study are included in the manuscript and/or the Supplementary Files.

\section{AUTHOR CONTRIBUTIONS}

$\mathrm{HC}$ and XL designed, synthesized, and characterized polymeric semiconductors. JG, LY, YH, and YZ measured OFET devices. LZ conducted the CV experiments. ZM performed DFT calculations. All authors were responsible for discussing the results. HC designed experiments and wrote the manuscript. 


\section{FUNDING}

National Natural Science Foundation of China (21875202, 61804051, 61890941), the Hunan Provincial Natural Science Foundation of China (2018JJ1024), the Science and Technology Planning Project of Hunan Province (2017RS3048), and the Research Foundation of Education Bureau of Hunan Province (17B253).

\section{ACKNOWLEDGMENTS}

The authors acknowledge Prof. Zebing Zeng (Hunan University) for his assistance in UV-Vis-NIR absorption

\section{REFERENCES}

Cai, Z., Zhao, D., Sharapov, V., Awais, M. A., Zhang, N., Chen, W., et al. (2018). Enhancement in open-circuit voltage in organic solar cells by using laddertype nonfullerene acceptors. ACS Appl. Mater. Interfaces 10, 13528-13533. doi: 10.1021/acsami.8b01308

Cai, Z. X., Vázquez, R. J., Zhao, D. L., Li, L. W., Lo, W., Zhang, N., et al. (2017). Two photon absorption study of low-bandgap, fully conjugated perylene diimide-thienoacene-perylene diimide ladder-type molecules. Chem. Mater. 29, 6726-6732. doi: 10.1021/acs.chemmater.7b01512

Chen, H., Liu, Z., Zhao, Z., Zheng, L., Tan, S., and Yin, Z. (2016). Synthesis, structural characterization, and field-effect transistor properties of n-channel semiconducting polymers containing five-membered heterocyclic acceptors: superiority of thiadiazole compared with oxadiazole. ACS Appl. Mater. Interfaces 8, 33051-33059. doi: 10.1021/acsami.6b12540

Chen, H. J., Guo, Y. L., Yu, G., Zhao, Y., Zhang, J., and Gao, D. (2012). Highly $\pi$-extended copolymers with diketopyrrolopyrrole moieties for highperformance field-effect transistors. Adv. Mater. Weinheim. 24, 4618-4622. doi: 10.1002/adma.201201318

Chen, X., Guo, Y. L., Tan, L. X., Yang, G., Li, Y. H., Zhang, G. X., et al. (2013). Dithiazole-fused naphthalene diimides toward new n-type semiconductors. $J$. Mater. Chem. C 1, 1087-1092. doi: 10.1039/C2TC00308B

Cheng, Y.-J., Yang, S.-H., and Hsu, C.-S. (2009). Synthesis of conjugated polymers for organic solar cell applications. Chem. Rev. 109, 5868-5923. doi: $10.1021 / \mathrm{cr} 900182 \mathrm{~s}$

Choi, H., Paek, S., Song, J., Kim, C., Cho, N., and Ko, J. (2011). Synthesis of annulated thiophene perylene bisimide analogues: their applications to bulk heterojunction organic solar cells. Chem. Commun. 47, 5509-5511. doi: $10.1039 / \mathrm{c0cc} 05448 \mathrm{~h}$

Cui, W. B., and Wudl, F. (2013). Dithienylbenzodipyrrolidone: new acceptor for donor-acceptor low band gap polymers. Macromolecules 46, 7232-7238. doi: 10.1021/ma400008h

Ding, L., Yang, C. Y., Su, Z. M., and Pei, J. (2015). Synthesis, crystal structure, and application of an acenaphtho[1,2-k]fluoranthene diimide derivative. Sci. China Chem. 58, 364-369. doi: 10.1007/s11426-014-5282-9

Dou, L., Liu, Y., Hong, Z., Li, G., and Yang, Y. (2015). Low-bandgap nearIR conjugated polymers/molecules for organic electronics. Chem. Rev. 115, 12633-12665. doi: 10.1021/acs.chemrev.5b00165

Fei, Z. P., Han, Y., Martin, J., Scholes, F. H., Al-Hashimi, M., AlQaradawi, S. Y., et al. (2016). Conjugated copolymers of vinylene flanked naphthalene diimide. Macromolecules 49, 6384-6393. doi: 10.1021/acs.macromol.6b01423

Fukutomi, Y., Nakano, M., Hu, J. Y., Osaka, I., and Takimiya, K. (2013). Naphthodithiophenediimide (NDTI): synthesis, structure, and applications. J. Am. Chem. Soc. 135, 11445-11448. doi: 10.1021/ja404753r

Gao, Y., Deng, Y. F., Tian, H., Zhang, J., Yan, D., and Geng, Y. (2017). Multifluorination toward high-mobility ambipolar and unipolar n-type donoracceptor conjugated polymers based on isoindigo. Adv. Mater. Weinheim. 29:1606217. doi: 10.1002/adma.201606217 measurements. This work was financially supported by the National Natural Science Foundation of China (21875202, 61804051, 61890941), the Hunan Provincial Natural Science Foundation of China (2018JJ1024), the Science and Technology Planning Project of Hunan Province (2017RS3048), and the Research Foundation of Education Bureau of Hunan Province (17B253).

\section{SUPPLEMENTARY MATERIAL}

The Supplementary Material for this article can be found online at: https://www.frontiersin.org/articles/10.3389/fchem. 2019.00362/full\#supplementary-material

Gao, Y., Zhang, X., Tian, H., Zhang, J., Yan, D., and Geng, Y. (2015). High mobility ambipolar diketopyrrolopyrrole-based conjugated polymer synthesized via direct arylation polycondensation. Adv. Mater. Weinheim. 27, 6753-6759. doi: 10.1002/adma.201502896

Gong, X., Tong, M., Xia, Y., Cai, W., Moon, J. S., Cao, Y., et al. (2009). Highdetectivity polymer photodetectors with spectral response from $300 \mathrm{~nm}$ to $1450 \mathrm{~nm}$. Science 325, 1665-1667. doi: 10.1126/science.1176706

Grimsdale, A. C., Chan, K. L., Martin, R. E., Jokisz, P. G., and Homlmes, A. B. (2009). Synthesis of light-emitting conjugated polymers for applications in electroluminescent devices. Chem. Rev. 109, 897-1091. doi: 10.1021/cr000013v

Guo, X. G., Facchetti, A., and Marks, T. J. (2014). Imide- and amide-functionalized polymer semiconductors. Chem. Rev. 114, 8943-9021. doi: 10.1021/cr500225d

Guo, X. G., and Watson, M. D. (2008). Conjugated polymers from naphthalene bisimide. Org. Lett. 10, 5333-5336. doi: 10.1021/ol801918y

Guo, X. G., and Watson, M. D. (2011). Pyromellitic diimide-based donoracceptor poly(phenyleneethynylene)s. Macromolecules 44, 6711-6716. doi: 10.1021/ma2009063

Guo, Y. K., Awartani, O., Han, H., Zhao, J. B., Ade, H., Yan, H., et al. (2017). Improved performance of all-polymer solar cells enabled by naphthodiperylenetetraimide-based polymer acceptor. Adv. Mater. Weinheim. 29:1700309. doi: 10.1002/adma.201700309

Hendriks, K. H., Heintges, G. H. L., Gevaerts, V. S., Wienk, M. W., and Janssen, R. A. J. (2013). High-molecular-weight regular alternating diketopyrrolopyrrolebased terpolymers for efficient organic solar cells. Angew. Chem. Int. Ed. 52, 8341-8344. doi: 10.1002/anie.201302319

Hu, Y. Y., Jiang, L., Chen, Q. J., Guo, J., and Chen, Z. J. (2018). Direct observation of the dipole-induced energetic disorder in rubrene single-crystal transistors by scanning kelvin probe microscopy. J. Phys. Chem. Lett. 9, 2869-2873. doi: 10.1021/acs.jpclett.8b01274

Hwang, Y. J., Kim, F. S., Xin, H., and Jenekhe, S. A. (2012). New thienothiadiazolebased conjugated copolymers for electronics and optoelectronics. Macromolecules 45, 3732-3739. doi: 10.1021/ma3000797

Ishikawa, H., Katayama, K., Nishida, J., Kitamura, C., and Kawase, T. (2018). Fluoranthene and its $\pi$-extended diimides: construction of new electron acceptors. Tetrahedron Lett. 59, 3782-3786. doi: 10.1016/j.tetlet.2018.09.012

Kim, J., Yun, M., Anant, P., Cho, S., Jacob, J., Kim, J. Y., et al. (2011). Copolymers comprising 2,7-carbazole and bis-benzothiadiazole units for bulk-heterojunction solar cells. Chem. Eur. J. 17, 14681-14688. doi: 10.1002/chem.201101258

Lei, T., Fan, Y. L., Liu, C. J., Yuan, S. C., and Pei, J. (2011). High-performance airstable organic field-effect transistors: isoindigo-based conjugated polymers. $J$. Am. Chem. Soc. 133, 6099-6101. doi: 10.1021/ja111066r

Li, H. Y., Kim, F. S., Ren, G. Q., Hollenbeck, E. C., Subramaniyan, S., and Jenekhe, S. A. (2013b). Tetraazabenzodifluoranthene diimides: building blocks for solution-processable n-type organic semiconductors. Angew. Chem. Int. Ed. 52, 5513-5517. doi: 10.1002/anie.201210085

Li, H. Y., Kim, F. S., Ren, G. Q., and Jenekhe, S. A. (2013a). High-mobility n-type conjugated polymers based on electron-deficient tetraazabenzodifluoranthene 
diimide for organic electronics. J. Am. Chem. Soc. 135, 14920-14923. doi: $10.1021 /$ ja407471b

Li, W. W., Hendriks, K. H., Furlan, A., Roelofs, C., Wienk, M. M., and Janssen, R. A. J. (2013c). Universal correlation between fibril width and quantum efficiency in diketopyrrolopyrrole-based polymer solar cells. J. Am. Chem. Soc. 135, 18942-18948. doi: 10.1021/ja4101003

Li, Y. N., Sonar, P., Singh, S. P., Soh, M. S., van Meurs, M., and Tan, J. (2011). Annealing-free high-mobility diketopyrrolopyrrole-quaterthiophene copolymer for solution-processed organic thin film transistors. J. Am. Chem. Soc. 133, 2198-2204. doi: 10.1021/ja1085996

Li, Z. J., Xu, X. F., Zhang, W., Meng, X. Y., Ma, W., Yartsev, A., et al. (2016). High performance all-polymer solar cells by synergistic effects of fine-tuned crystallinity and solvent annealing. J. Am. Chem. Soc. 138, 10935-10944. doi: 10.1021/jacs.6b04822

Li, Z. Y., Ying, L., Zhu, P., Zhong, W. K., Li, N., Liu, F., et al. (2019). A generic green solvent concept boosting the power conversion efficiency of all-polymer solar cells to 11\%. Energy Environ. Sci. 12, 157-163. doi: 10.1039/C8EE02863J

Mei, C. Y., Liang, L., Zhao, F. G., Wang, J. T., Yu, L. F., Li, Y. X., et al. (2013). A family of donor-acceptor photovoltaic polymers with fused 4,7dithienyl-2,1,3-benzothiadiazole units: effect of structural fusion and side chains. Macromolecules 46, 7920-7931. doi: 10.1021/ma401298g

Mei, J. G., Kim, D. H., Ayzner, A. L., Toney, M. F., and Bao, Z. N. (2011). Siloxaneterminated solubilizing side chains: bringing conjugated polymer backbones closer and boosting hole mobilities in thin-film transistors. J. Am. Chem. Soc. 133, 20130-20133. doi: 10.1021/ja209328m

Sariciftci, N. S. (1997). Primary Photoexcitations in Conjugated Polymers: Molecular Excitons vs Semiconductor Band Model. Singapore: World Scientific. doi: $10.1142 / 3299$

Senkovskyy, V., Tkachov, R., Komber, H., Sommer, M., Heuken, M., Voit, B., et al. (2011). Chain-growth polymerization of unusual anion-radical monomers based on naphthalene diimide: a new route to well-defined n-type conjugated copolymers. J. Am. Chem. Soc. 133, 19966-19970. doi: 10.1021/ja208710x

Stalder, R., Mei, J. G., and Reynolds, J. R. (2010). Isoindigo-based donor-acceptor conjugated polymers. Macromolecules 43, 8348-8352. doi: 10.1021/ma1018445

Usta, H., Newman, C., Chen, Z. H., and Facchetti, A. (2012). Dithienocoronenediimide-based copolymers as novel ambipolar semiconductors for organic thin-film transistors. Adv. Mater. Weinheim. 24, 3678-3684. doi: 10.1002/adma.201201014

Walker, W., Veldman, B., Chiechi, R., Patil, S., Bendikov, M., and Wudl, F. (2008). Visible and near-infrared absorbing, low band gap conjugated oligomers based on cyclopentadieneones. Macromolecules 41, 7278-7280. doi: $10.1021 / \mathrm{ma} 8004873$

Wang, Y., Hasegawa, T., Matsumoto, H., and Michinobu, T. (2019). Significant improvement of unipolar n-type transistor performances by manipulating the coplanar backbone conformation of electron-deficient polymers via hydrogen bonding. J. Am. Chem. Soc. 141, 3566-3575. doi: 10.1021/ jacs.8b12499

Yan, H., Chen, Z. H., Zheng, Y., Newman, C., Quinn, J. R., Dotz, F., et al. (2009). A high-mobility electron-transporting polymer for printed transistors. Nature 457, 679-686. doi: 10.1038/nature07727
Yang, C. D., Cho, S., Chiechi, R. C., Walker, W., Coates, N. E., Moses, D., et al. (2008). Visible-near infrared absorbing dithienylcyclopentadienonethiophene copolymers for organic thin-film transistors. J. Am. Chem. Soc. 130, 16524-16526. doi: 10.1021/ja806784e

Yang, J., Zhao, Z. Y., Wang, S., Guo, Y. L., and Liu, Y. Q. (2018). Insight into highperformance conjugated polymers for organic field-effect transistors. Chem 4, 2748-2785. doi: 10.1016/j.chempr.2018.08.005

Zhan, X. W., Facchetti, A., Barlow, S., Marks, T. J., Ratner, M. A., Wasielewski, M. R., et al. (2011). Rylene and related diimides for organic electronics. Adv. Mater. Weinheim. 23, 268-284. doi: 10.1002/adma.201001402

Zhan, X. W., Tan, Z. A., Domercq, B., An, Z. S., Zhang, X., Barlow, S., et al. (2007). A high-mobility electron-transport polymer with broad absorption and its use in field-effect transistors and all-polymer solar cells. J. Am. Chem. Soc. 129, 7246-7247. doi: 10.1021/ja071760d

Zhang, X., Steckler, T. T., Dasari, R. R., Ohira, S., Potscavage, W. J., Tiwari, J. S. P., et al. (2010). Dithienopyrrole-based donor-acceptor copolymers: low band-gap materials for charge transport, photovoltaics and electrochromism. J. Mater. Chem. 20, 123-134. doi: 10.1039/B915940A

Zhao, Y., Zhao, X. K., Zang, Y. P., Di, C. A., Diao, Y., and Mei, J. G. (2015). Conjugation-break spacers in semiconducting polymers: impact on polymer processability and charge transport properties. Macromolecules 48, 2048-2053. doi: 10.1021/acs.macromol.5b00194

Zhao, Z. Y., Yin, Z. H., Chen, H. J., Zheng, L. P., Zhu, C. G., Zhang, L., et al. (2017). High-performance, sir-stable field-effect transistors based on heteroatom-substituted naphthalenediimide-benzothiadiazole copolymers exhibiting ultrahigh electron mobility up to $8.5 \mathrm{~cm}^{2} \mathrm{~V}^{-1} \mathrm{~s}^{-1}$. Adv. Mater. Weinheim. 29:1602410. doi: 10.1002/adma.201602410

Zhou, W. Y., Jin, F., Huang, X. B., Duan, X. M., and Zhan, X. W. (2012). A low-bandgap conjugated copolymer based on porphyrin and dithienocoronene diimide with strong two-photon absorption. Macromolecules 45, 7823-7828. doi: $10.1021 / \mathrm{ma} 3015257$

Zhu, C. G., Zhao, Z. Y., Chen, H. J., Zheng, L. P., Li, X. L., Chen, J. Y., et al. (2017) Regioregular bis-pyridal[2,1,3]thiadiazole-based semiconducting polymer for high-performance ambipolar transistors. J. Am. Chem. Soc. 139, 17735-17738. doi: $10.1021 /$ jacs.7b10256

Zou, Y. P., Gendron, D., Neagu-Plesu, R., and Leclerc, M. (2009). Synthesis and characterization of new low-bandgap diketopyrrolopyrrole-based copolymers. Macromolecules 42, 6361-6365. doi: 10.1021/ma901114j

Conflict of Interest Statement: The authors declare that the research was conducted in the absence of any commercial or financial relationships that could be construed as a potential conflict of interest.

Copyright (c) 2019 Li, Guo, Yang, Chao, Zheng, Ma, Hu, Zhao, Chen and Liu. This is an open-access article distributed under the terms of the Creative Commons Attribution License (CC BY). The use, distribution or reproduction in other forums is permitted, provided the original author(s) and the copyright owner(s) are credited and that the original publication in this journal is cited, in accordance with accepted academic practice. No use, distribution or reproduction is permitted which does not comply with these terms. 